\title{
Loss of Agricultural Land: A Case Study of Tha Chin River Basin, Influenced by Water Diversion to the West
}

\author{
Panarat Chengcharoen, Pricha Dhanmanonda, and Kasem Chunkao
}

\begin{abstract}
Tha Chin River is a major river in the central plateau from the past to the present. Tha Chin river, separated from the river to Chainat. And runs almost parallel to the river in the province through the stuff into the Gulf of Thailand, Nakhon Pathom, Samut Sakhon province by the year 2011 through the Tha Chin River Basin area of the West Bank has experienced major flooding over the years. The areas near the Chao Phraya River and the Gulf of Thailand to flood conditions on the sea level rise driven by The man tried exploitation of land resources as much as possible in a variety of formats. The agricultural land use, etc., fishing industry in Thailand. Has changed over time, from past to present. Of the problems mentioned above. Researchers are interested in studying the impact of the loss of agricultural land flooding the Tha Chin River Basin influenced by the west side of the drainage. Affecting land use change in the Tha Chin River Basin. The results of this study may be used as supporting data and the schedule of the planned flood protection planning. To avoid the loss of important agricultural area and economic and social.
\end{abstract}

Index Terms-Loss of agricultural land, Tha Chin River basin, influenced water diversion.

\section{INTRODUCTION}

Tha Chin River has been the important river in the central basin. This one was separated from Chao Phraya river, that Chai Nat province. This flow along with Chao Phraya river through Suphan Buri, Nakhon Pathom, and finish at the Gulf of Thailand in the Samutprakan province in 2011. in the west basin of a Tha Chin river area affected by the flood more than in the past, then the urban area (is near the Chao Phraya river and Gulf of Thailand), has normally affected by the flood water. Flood condition occurring on a regular basis. Even don't to cause serious damage to property directly. Because people in the area are familiar and prior knowledge with the problem that short term flooding, So be prepared to help themselves to a certain extent. But the flood water is cause economic damage to the thread and opportunity to develop the area suffered a tautology. Agricultural land use, which has created a lot of revenue for the country.

The land is a natural resource that is necessary to sustain human life. The four factors to be considered as a basic human need that was different from the improvement and development of its land. Sometimes it can be said that the land is one factor in the production of things. To satisfy human needs. So people are trying to profit from the land resources in a variety of agriculture, Fishery, Industry etc.

Manuscript received December 4, 2012; revised February 7, 2013.

Panarat Chengcharoen, Pricha Dhanmanonda, and Kasem Chunkao are with the Environmental Science Department, Faculty of Science, Kasetsart University. 50 Namwongvan Rd, Chatuchak Bangkok 10900, Thailand (e-mail: g5315800130@ku.ac.th, fforprd@ku.ac.th, ecksc@ku.ac.th).
Land use in Thailand has changed over time, from past to present. Flood condition occurring of Tha Chin river was be severe more than before, the organization concerned about this basin but focus on water quality management, including water quantity that did not balance with demand, was a big problem no less than water quantity. A lack of water for agriculture in the dry season, and the flood rainy season has normally appeared, so it will change and effect to people, who were around there.

\section{MATERIAL AND METHOD}

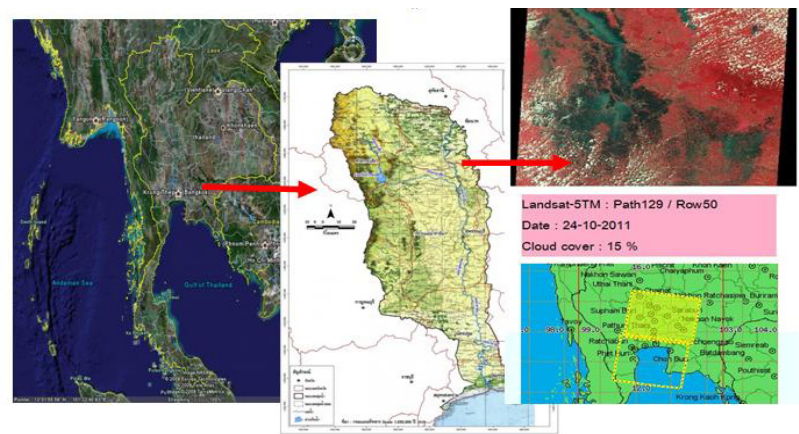

Fig. 1. Study area

\section{A. Study Area}

Tha Chin River Basin is located in the Central Plain of Thailand. Total basin area is 13,681 square kilometers. The length of the river, and every river is about $349 \mathrm{~km}$ and a major river flowing through the basin, only one is the Tha Chin River, which at a length of about $325 \mathrm{~km}$ Tha Chin River separates the right bank of the river district. Makhamtao. Wat Sing district. Chainat. Flow into the Gulf of Thailand, Suphan Buri and Nakhon Pathom, Samut Sakhon province (Fig. 1).

\section{B. Experimental}

In this study, the system will look at the extent of the drainage area of the basin, Chin. By limiting the analysis to the extent the flow of water on the surface only. The user can select a specific area that has been damaged by agricultural drainage basin in the west coast port of China.

Study area is to find ways to prevent the loss of agricultural areas. Since the major floods have occurred in August December 2011 to protect the loss of important agricultural areas.

\section{Methodology}

Study and analyze the status of agricultural land use and land use change after the 2011 flood to drainage on the west side of the loss of agricultural areas. By the land use data, the 
area flooded in 2011 and the influence of agriculture on the west side of the drainage. Overlaying with geographic information system from which to explore Landsat 5 TM satellite images and field data collected in the study area. By observing the area has been damaged by water and agricultural land that remains today. Be compared to spatial damage. Andvegetation characteristics of the area, as well as economic importance. And analysis of data from field surveys together with information derived from satellite imagery interpretation $(3,7)$. Then processed using geographic information systems. To create 3D models (Fig. 2).

TABLE I: LAND USE IN THE THA CHIN RIVER BASIN

\begin{tabular}{|c|c|c|c|c|}
\hline \multirow{3}{*}{ Province } & \multirow{3}{*}{ Area (hectares) } & \multicolumn{3}{|c|}{ Land use in the Tha Chin River Basin } \\
\hline & & Agriculture & forestry & Other \\
\hline & & Percentage & Percentage & Percentage \\
\hline Chai Nat & 247893.76 & 66.61 & 15.85 & 17.54 \\
\hline Suphan Buri & 535800.8 & 60.08 & 10.45 & 29.46 \\
\hline Nakhon Pathom & 216832.64 & 62.57 & 0.00 & 37.43 \\
\hline Samut Sakhon & 87234.56 & 34.42 & 2.97 & 62.61 \\
\hline Total & 1087761.76 & 62.90 & 6.11 & 30.99 \\
\hline
\end{tabular}

\begin{tabular}{llll}
\multicolumn{5}{c}{ TABLE II: SUMMARY OF CHANGES IN LAND USE IN THE YEAR 1995-2010 } \\
\hline Watershed & Land use in 1995 & Land use in 2010 & Area (hectares) \\
\hline \multirow{3}{*}{ Tha Chin River Basin } & Agriculture & Urban areas & 89633.28 \\
& Forestry & Urban areas & 1131.84 \\
& Industry & Urban areas & 1677.76 \\
& Water resources & Urban areas & 3708.16 \\
& Other & Urban areas & 1475.68 \\
\hline
\end{tabular}

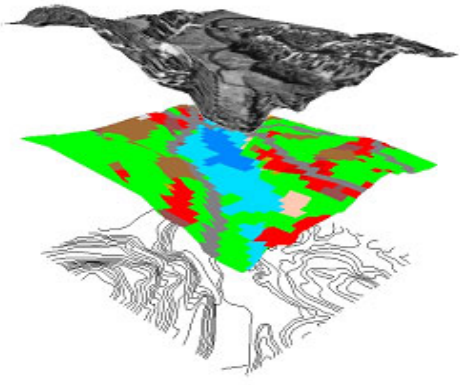

Fig. 2. Overlay of geographic information systems and satellite imagery.

\section{RESUlTS AND DisCUSSION}

\section{A. The General Condition}

The general condition of the Tha Chin River Basin. At the foot of the hill on the west side. But there is not very high. Upper East Side. The middle and lower part of the alluvial plain. The Upper East Side is a flat, alluvial plain with Chao. Central and lower plains with alluvial plains Leg. Most of the watershed area is suitable for agriculture from the table that shows the land use of the four provinces in the Tha Chin River Basin found that 63 percent of the total area is agricultural land. An area of approximately 6 percent of the remaining forest area is more useful if the province's agricultural areas are mainly located in the province of Suphan Buri, Chai Nat, and Samut Sakhon Nakhon section. Agriculture occupies about 34 percent of the area of the province (Table I).

\section{B. Trends in Land Use}

Trends in land use of the Tha Chin River Basin. Is needed in the watershed management plan. The trends of changes in land use in the watershed Chin. The influence of drainage on the west side of the flood in the year 2011 by studying the pattern of land use in the past with the present land use pattern is made. The analyzed area is likely to change. The area has been a change to the land use. The study of land use change using satellite imagery is often faced with the problem that this method is used. Land use patterns in the data. Have been conducted in the province. The present study focuses on the management of the watershed. Therefore, the information in it is sometimes quite difficult. The scope of some provinces may cover more than one area of the basin. Comparison of the changes in land use, as mentioned above. I conclude that the expansion of urban areas. Is the most striking changes in the drainage basin (Fig. 3 and Table 2).

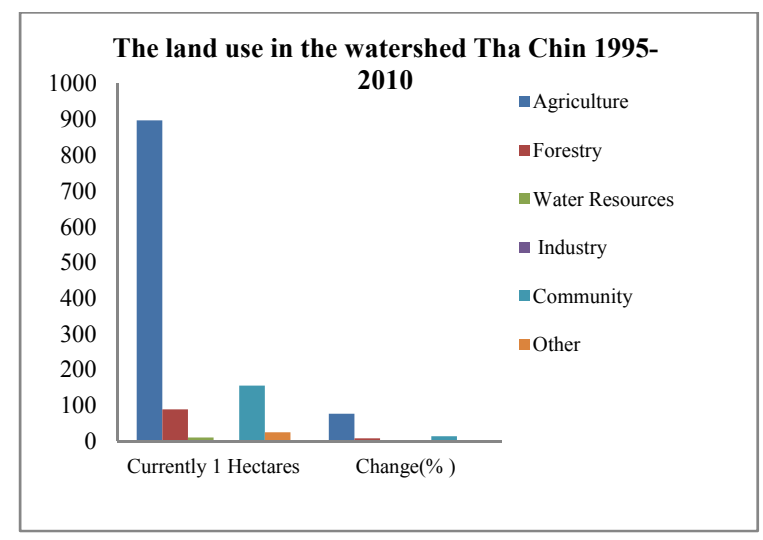

Fig. 3. The land use in the watershed Tha Chin in Thailand 1995-2011

\section{Situation and Problems of Water Resources.}

Tha Chin River Basin, which has exclusive perfume Tha Chin River is the main river of the state as a vast alluvial plains of the Chao Phraya river basin, including the Tha Chin River Basin Creek mine I have a 1788 sq km catchment area. And topped with Tha Chin River Basin area 11,893 square kilometers. Total drainage area of the basin is 13,681 square kilometers. Amount of rainfall in the Tha Chin River Basin averaged over 680.4 to $1325.0 \mathrm{~mm}$ per year, with 88 percent 
of the total annual rainfall. Rain falls between May and October. Runoff in the watershed is 6376 million cubic meters ([1], [2], [6]) abdominal surgery. Tha Chin River Basin, an area that is in the watershed to watershed $1 \mathrm{~A} 5.5$ percent to 1.3 percent of the remaining two classes, about 93 percent of the watershed to 3-5 wetlands of national significance is. central plains and the lower Tha Chin River Swamp Hunting Chawak. The wetland is an important local source of water cost in 2577 of the Tha Chin River Basin, including dam Krasiao. Crescent Creek District, Defense barred action. Suporn drive Buri province. The reservoir has a capacity of 240 million cubic meters.

\section{CONCLUSION}

The effects of flooding through loss of farmland, the Tha Chin River Basin influenced by the west side of the drainage. Affecting land use change in the Tha Chin River Basin by the year 2011 through the Tha Chin River Basin area of the West Bank has experienced major flooding over the years. The areas near the Chao Phraya River and the Gulf of Thailand to flood conditions on the sea level rise driven by The man tried exploitation of land resources as much as possible in a variety of ways in which people are engaged in agriculture, mainly the cultivation of crops such as fruit trees and livestock. The area is mostly plain. The major rivers flowing through ([4],[5], [6] )the Chao Phraya River and the Little River and Tha Chin River. The land use in the agricultural sector, 51.70 percent of the forest area of only 6.11 per cent of the forest area of Nakhon Pathom province is now. And the area of the other 31 percent of the area of the cold 6,798,511 acres addition to soil and land use in industrial commercial and handicrafts respectively of this study may be used as supporting data for planning flood control and scheduling planning. To avoid the loss of important agricultural area and economic and social

\section{ACKNOWLEDGMENT}

The research is financed by the King's Royally Initiated LeamPhakBia Environmental Research and Developmental Project

\section{REFERENCES}

[1] K. Chankaw, "Near surface meteorology," Department of Conservation, Faculty of Forestry, Kasetsart University, Bangkok, 1979.

[2] V. N. Kudeyarov and I. N. Nurganova, "Carbon dioxide emissions and net primary production of Russian terrestrial ecosystems," Biol. Fertil. Soils, vol. 27, pp. 246-250, 1998.

[3] OEPP. 2000., "Thailand's national greenhouse gas inventory," Ministry of Science, Technology and Environment, Bangkok, pp. 118, 1994.

[4] Y. Takaya, "Agricultural Development of a Tropical Delta: A Study of the Chao Phraya Delta," University of Hawaii Press, Honolulu, Hawaii, 1987

[5] S. Tanabe, "Land Reclamation in the Chao Phraya Thailand: A Rice-Growing Society The University Press of Hawaii," Honolulu, Hawaii, 1978.

[6] Y. Kaida, "Hydrology of Ricelands In: Soil physics and Rice," International Rice Research Institute (IRRI), Los Banos, Philippines. 1985

[7] T. M. Lillesand and R. W. Kiefer, Remote Sensing and Image Interpretation, 3rd ed. John Wiley \& Sun, Inc., New York, 1994.

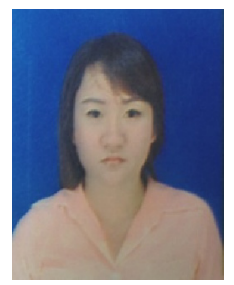

Panarat Chengcharoen was born on 3 February 1986 in Bangkok. She got her Bachelor of Environment Science (B. Sc.). She is now Faculty of Environment, Kasetsart University. 